This is a pre-copyedited version of an article accepted for publication in (Extrapolation -Wooster Oh-) following peer review. The definitive publisher-authenticated version is available through the University of Texas Press.

\title{
Virtual Histories and Counterfactual Myths: Christopher Priest's The Separation
}

\section{NICK HUBBLE}

Among the consequences of the ongoing crisis in academic historical studies provoked by postmodernist and poststructuralist theories (see Evans) has been the rise of both popular and counterfactual history. These developments can be seen simultaneously in the recent success of collections such as Virtual History (1997) edited by Niall Ferguson and the two volumes edited by Robert Cowley, What If? (1999) and More What If? (2001). The UK editions of these books all feature Adolf Hitler prominently on their covers with swastikas variously draped over the Houses of Parliament or superimposed on Union Jacks. The idea of Nazi triumph has long held a popular currency, reflected in the success of thrillers such as Robert Harris's Fatherland (1992) and Len Deighton's SS-GB (1978). The idea even predates the Second World War, with the 1937 Swastika Night by Katherine Burdekin (writing as Murray Constantine) depicting Europe after seven centuries of Nazi domination. It is a staple enough theme in science fiction to have a detailed entry by John Clute, "Hitler Wins," in The Encyclopedia of Science Fiction and, of course, the idea is central to the classic alternate history, Philip K. Dick's The Man in the High Castle (1962). The best account of the illicit pleasure involved in this potentially seamy subgenre was written by George Orwell in 1940:

I should like to put it on record that I have never been able to dislike Hitler . . . The fact is that there is something deeply appealing about him. One feels it again when one sees his photographs ... It is a pathetic, doglike face, the face of a man suffering under intolerable wrongs ... He is the martyr, the victim, 
This is a pre-copyedited version of an article accepted for publication in (Extrapolation -Wooster Oh-) following peer review. The definitive publisher-authenticated version is available through the University of Texas Press.

Prometheus chained to the rock, the self-sacrificing hero who fights singlehandedly against impossible odds ... One feels, as with Napoleon, that he is fighting against destiny, that he can't win, and yet that he somehow deserves to. The attraction of such a pose is of course enormous; half the films that one sees turn upon some such theme. (Orwell 117-18)

While Christopher Priest's The Separation deserves to be widely read and acknowledged as a classic alternate history, it does not simply replay the populist trope of Nazi victory and barely mentions Hitler. Instead, the key counterfactual scenario is the signing of an armistice between Britain and Germany in May 1941. By contrasting The Separation with some of the examples of recent popular history given above, I hope to draw some conclusions about the pleasure and the pain inherent to the counterfactual form.

In Niall Ferguson's introduction to Virtual History he suggests that there are "two distinct forms of counterfactual which have been used by historians: those which are essentially the products of imagination but (generally) lack an empirical basis; and those designed to test hypotheses by (supposedly) empirical means" (Ferguson 18). While Ferguson is arguing that modern counterfactuals can transcend this division, it is still possible to employ these distinctions in a revised form. For example, in More What If?, the historical novelist Cecelia Holland speculates on the Danish-Saxon Harold winning the Battle of Hastings. If the broader Scandinavian civilization had been able to retain its links to wealthy England in this manner, she speculates that it would have remained powerful enough to maintain and expand its North American settlements by trade and co-operation (Vikings not possessing the technological superiority over the Native Americans that future European colonists would exploit) so that "perhaps a blended culture might have arisen in the dark forests and lakes of 
This is a pre-copyedited version of an article accepted for publication in (Extrapolation -Wooster Oh-) following peer review. The definitive publisher-authenticated version is available through the University of Texas Press.

the New World—a Viking-Mohawk republic" (Holland 79). A republican trade-based commonwealth would have become the dominant global form and not the European absolutist model of the state, which has plagued the world for hundreds of years. This is clearly an exercise in counterfactual imagination, but one only has to think of the frequency with which the trope of the "Norman yoke" appears in British Marxist history to realize how central this type of imagination is to history in general.

On the other hand, in the first What If? Volume, Victor Davis Hanson claims to consider the consequences of the Persians defeating the Greeks at Salamis in 480 BC, but his conclusion concerns our history and not the counterfactual one: "What later philosophers such as Hegel, Nietzsche and Spengler would deplore about Western culture - its rampant equality, uniform sameness, and interest in crass material bounty —in some sense started at Salamis, an unfortunate "accident", Aristotle said, but one that nevertheless shifted forever the emphasis of Western civilization toward more egalitarian democracy and a more capitalistic economy" (Hanson 34-35). Here, imagination remains subordinate to the primary aim of confirming the hypothesis that the West is the best. Indeed, Hanson has also written a full book-length account of Why the West was Won (2002). Such ideological propaganda forms the majority of the two What If? Books, but its influence extends much further. Philip Bobbitt's The Shield of Achilles has been described as "the most extended theorization of the constitutional imperative to crush states that are insufficiently respectful of human rights, or the oligopoly of nuclear weapons" (Anderson 16n). That is to say it justifies the logic of pre-emption that forms current US foreign policy with an eight hundred page account of "War, Peace and the Course of History". A central tenet of Bobbitt's introduction is the need to extend contemporary imagination beyond presentism and contradict the commonsense viewpoint that evaluates future states of affairs by comparison with the present. His example makes this clear: 
This is a pre-copyedited version of an article accepted for publication in (Extrapolation -Wooster Oh-) following peer review. The definitive publisher-authenticated version is available through the University of Texas Press.

One encounters this often in daily life, in the adolescent's decision to quit school so "I can make more money" (because going to school pays less than working in a fast-food shop) ... the speaker is making the mistake of comparing a future state of affairs with the present, and omitting to imagine what an alternative future state of affairs might be like ... (Bobbitt 10)

Bobbitt uses this example to refute those criticisms of the NATO action in the Balkans, which were made on the not unreasonable grounds that intervention has worsened the lot of the people. This is a logical fallacy for him because the only criteria for judgment that he will accept for assessing the outcome of any action is a comparison with the counterfactual scenario imagined as a result of that action not taking place. To take another topical example, it does not matter that conquering Iraq appears to be giving rise to increasingly disastrous consequences, just as long as worse counterfactual scenarios can continue to be imagined ... and conservative political commentators can always imagine something worse! As Bobbitt cheerfully concludes:

The epochal war we are about to enter will either be a series of low-intensity, information-guided wars linked by a commitment to re-enforcing world order, or a gradually increasing anarchy that leads to intervention at a much costlier level or even a cataclysm of global proportions preceded by a period of relative if deceptive peace. It is ours to choose. (Bobbitt 342)

The choice we are being presented with is "America or Armageddon?". And that is the real beauty of counterfactual history: by its apparent celebration of choice and contingency, it enables its proponents to remain unrelentingly teleological while 
This is a pre-copyedited version of an article accepted for publication in (Extrapolation -Wooster Oh-) following peer review. The definitive publisher-authenticated version is available through the University of Texas Press.

immune to accusations of determinism. In short, this is not history at all but the pinnacle of myth: theology. We are being told that the West rules by divine grace as witnessed by the words of the eminent historian, John Lukacs:

Had Hitler won the Second World War we would be living in a different world . . Churchill, was like King Canute, attempting to withstand and sweep back that wave. And-yes, mirabile dictu — this King Canute succeeded: because of his resolution and - allow me to say this - because of God's will, of which like every human being, he was but an instrument.

... At best, civilization may survive, at least in some small part due to Churchill in 1940. At worst, he helped to give us fifty years. Fifty years before the rise of new kinds of barbarianism not incarnated by the armed might of Germans or Russians, before the clouds of a new Dark Age may darken the lives of our children and grandchildren. (Lukacs 217-19)

This is the authentic voice of the millenarian prophet forecasting apocalypse, unaware that he is chasing his own unconscious projections and mouthing the Fascist logic of better an end in horror than horror without end. Meanwhile, the whole process provides a classic example of Roland Barthes's theory of how myth appropriates meaning as the departure point for its own second-order semiological system (see Barthes 117-74). That Churchill's resolve helped keep Britain in the Second World War and contributed to the eventual victory of the Allies is a matter of fact, but to use that fact to signify the saving of civilization as we know it is pure mystification. Furthermore, it is imbuing Churchill with exactly those qualities of fighting alone against impossible odds that Orwell ascribed to Hitler. Indeed the article by Orwell quoted earlier continues: "Whereas Socialism, and even capitalism in a more grudging way, have said to people "I offer you a good time," Hitler has said to them "I offer 
This is a pre-copyedited version of an article accepted for publication in (Extrapolation -Wooster Oh-) following peer review. The definitive publisher-authenticated version is available through the University of Texas Press.

you struggle, danger and death," and as a result a whole nation flings itself at his feet" (Orwell 118). As Peter Davison, the editor of The Complete Works of George Orwell, comments in an editorial note to that passage, it was barely a few months later that Churchill said in speech to the House of Commons on 13 May 1940: "I have nothing to offer but blood, toil, tears and sweat". It can be seen that it is the charismatic qualities that Churchill undoubtedly shared with Hitler, which are used to praise him. This mythicized version of Churchill — who was, don't forget, half American — has become the legitimating role model for self-sacrificing Anglo-American political leaders fighting single-handedly against destiny. Apart from anything else, this explains why Britain is inescapably wedded to American foreign policy and vice versa: the moral justification and self-understanding of the two states is now entirely grounded on the myth of their virtuous struggle against "evil" in the Second World War. Only if this link is broken can the direction of Anglo-American foreign politics be turned round.

Therefore, it can safely be said of the counterfactual scenario in The Separation, which Priest outlines via the device of an extract from a history book written in the alternate world, not only that it would be rejected if sent as a proposal to the editor of What If?, but also that it constitutes a direct political act in its own right:

After, Churchill's final and most sensational reversal of policy in May 1941, the USA felt itself released from all obligations to the British. Within four weeks of the British armistice, and two weeks before the beginning of Operation Barbarossa, they launched their series of pre-emptive attacks on expansionist Japan and the Japanese-occupied areas of mainland China. When Japan had been defeated, and the Bolshevist threat posed by the Maoist revolution had been crushed, the USA's opportunist alliance with Chiang Kai-shek's 
This is a pre-copyedited version of an article accepted for publication in (Extrapolation -Wooster Oh-) following peer review. The definitive publisher-authenticated version is available through the University of Texas Press.

Kuomintang enabled them to move swiftly on Manchuria and, eventually, across the vast eastern reaches of the Soviet Union.

The ... complex and dangerous war against communism was in effect fought by the Germans invading Russia from the west and the Americans from the east. With the dismantling of the Soviet Union after the cease-fire at the Urals, the two former superpowers then settled into the Third War stalemate. They both collapsed into economic and social stagnation as the incalculable costs of their wars were counted. From this ruin, only Germany so far has recovered—and then only with the aid of the denazification programme from the European Union. For the USA, the half-century of stalemate has been a disaster, still with no solution in sight. At the beginning of the twentieth century the USA was shaping into the newest and perhaps best democracy in the Western world. Instead, because of bad military decisions, corrupt civilian governments and a level of political inwardness that puts prewar isolationism into shade, it has become a shaky but authoritarian republic, run in effect by capitalist adventurers and armed militias, and undermined by social dissent, organized crime and a heavily armed populace. (299-300)

It is worth underlining, in these times when any expression of dissent provokes saturation propagandizing and polemics, that this is not anti-Americanism, but an acknowledgement that the betrayal of the potential of America has been one of the greatest tragedies of the twentieth century. Priest's book, therefore, illustrates not so much that this alternate world would be better than the one we inhabit, but that it can be deployed as a rival counterfactual myth to the currently hegemonic counterfactual myth of the triumph and virtue of the West. This is the response to myth that Barthes advocated: "Since myth robs language of something, why not rob myth? All that is 
This is a pre-copyedited version of an article accepted for publication in (Extrapolation -Wooster Oh-) following peer review. The definitive publisher-authenticated version is available through the University of Texas Press.

needed is to use it as the departure point for a third semiological chain, to take its signification as the first term of a second myth" (Barthes 147).

That Priest is consciously attempting some such maneuver can be deduced from the way that The Separation is structured. The novel's present is set in 1999 but, as the reader quickly comes to realize, it is 1999 in a parallel universe. However, because the protagonist, Stuart Gratton, is a life historian, we spend little time in this present apart from the opening pages and another brief interlude in the middle of the book. Either side of this interlude are extensive extracts from the memoirs and diaries respectively of a pair of identical twins, J. L. Sawyer and J. L. Sawyer. The first of these is mainly referred to as "J. L."-although sometimes as Jack—and is/was a pilot in Bomber Command, while the second, Joe, is/was a conscientious objector and a pacifist. As becomes eventually clear to Gratton, while Joe's diaries refer to the past of his world - i.e. the book's counterfactual present — in which there was an armistice between Britain and Germany in 1941, J. L.'s memoirs have been written from a different present existing in an alternate world, in which the war did not finish until 1945-i.e. our world. Joe died in an air-raid in November 1940 in our world and J. L. died in May 1941 after being shot down on what transpires to be the last bombing mission of the war in Gratton's world. Thus, as can readily be imagined, certain parallels, oppositions and points of ambiguity are generated by the narrative structure.

It is impossible to do full justice to the subtlety and complexity of Priest's writing, but by highlighting the various appearances of Churchill in the text, it is possible to provide something of the flavor as well as expounding on the theme I have taken for this article. In the opening section, we learn that Gratton's interest in Sawyer, whom he initially believes to be one man, was piqued by the second volume of Churchill's wartime memoirs, The German War: Volume II, Their Finest Hour (note the 
This is a pre-copyedited version of an article accepted for publication in (Extrapolation -Wooster Oh-) following peer review. The definitive publisher-authenticated version is available through the University of Texas Press.

counterfactual title). In a minute, dated 30 April 1941, included in Appendix B of the volume, "Churchill describes Sawyer as a conscientious objector who was also an operational RAF bomber pilot" (12). It is this mystery, combined with the intriguing fact that Gratton, an historian of the period, has never heard of Sawyer before, that inspires his subsequent research and, thus, the story which unfolds before us. He is handed a packet of J. L. Sawyer's memoirs by Sawyer's daughter at a book signing. This is a seemingly mundane scene which the reader increasingly thumbs back to as it becomes clear that J. L.'s memoirs are from our world and, therefore, that some sort of bridging of parallel universes has taken place in a back-street bookshop on a rainy afternoon - a sly reference to the fantasies of many readers. Anyway, as we read the memoirs of this bomber pilot we are introduced to the myth of Churchill that is familiar to us: "Churchill in those long and dangerous months before the USA, the Soviet Union and Japan were involved in the war, quickly became a legend to most ordinary British people. He seemed to some up a certain kind of British spirit, a symbol of British willingness to fight, perhaps never before identified until that need arose" (101).

In the interlude section in the middle of the book, when we return to the "present" of 1999, Gratton (who has yet to read the memoirs that we, the readers, just have) is still wondering if his idea of writing a book about Sawyer will turn out to be a fruitless occupation: "The puzzle could turn out to be not a puzzle at all, but a misunderstanding by Churchill, even a mistake or a misprint. It wouldn't be the first time that an idea for a book led nowhere. Nor would it be the first time historians had been misled by Churchill, that arch manipulator of twentieth-century history" (210). Here, the reader is being "softened up" for the assault on the Churchill myth that is coming in the second half of the book in the narrative by the pacifist twin, Joe. For example, his diary entry for 10 April 1940 reads: "Yesterday, Hitler sent his armies 
This is a pre-copyedited version of an article accepted for publication in (Extrapolation -Wooster Oh-) following peer review. The definitive publisher-authenticated version is available through the University of Texas Press.

into Denmark and Norway. I'm convinced the warmonger Churchill was ultimately behind it. Less than a week has passed since the Prime Minister put him in charge of the British war effort, as Churchill immediately claimed for himself" (260).

However, as we know, in this universe Churchill will undertake a sensational reversal of policy. The key moment — one is tempted to use Churchill's own terminology and call it the hinge of fate - is a Cabinet meeting on 7 May 1941, which Joe attends as a representative of the British Red Cross and part of a delegation presenting Churchill with the provisional draft of a peace agreement resulting from a secret meeting between German and British representatives held earlier that year. Churchill states his case forthrightly: "History is made by brave and imaginative decisions, not by tactical surrenders. I will not accept anything from your proposal. History this time demands we deal effectively with Hitler" (410-11). Sawyer then speaks for the first and only time in the meeting: "On the contrary, history shows that war always defeats its own object. No war in recorded history has produced a result that is in accordance with the stated aims of the victor" (411). He goes on to argue that the destruction of Germany could only result in the dominance of Communism in Europe with the direct consequence that the USA would intervene heavily in European affairs, before concluding: "Peace grasped at this moment offers the only hope for stability and harmony in the world" (411). Churchill thanks Sawyer for his insights and concludes in turn: "I am forced to consider the well-being of the country as a whole" (412).

Five days later on 12 May 1941, Churchill sat down with Deputy Führer Rudolf Hess in Stockholm and signed an armistice. The following day he broadcast to the country on the BBC: 
This is a pre-copyedited version of an article accepted for publication in (Extrapolation -Wooster Oh-) following peer review. The definitive publisher-authenticated version is available through the University of Texas Press.

There can be no greater or better news than word of peace ... The courage of the British race was never better shown, never admired more widely. Our finest hour followed, our most splendid year, our saving grace. Our tiny island, battered though it has become, bombarded though it was, and besieged as it has been, remained free. It is free now. And it will remain free forever (446).

As has been shown, by taking the myth of Churchill — the Greatest Briton according to a recent poll of BBC viewers - that dominates our present, Priest uses it as the point of departure for a new myth: a myth of peace rather than war. You may ask "Why accept this myth rather than the other one?" The answer, surprisingly perhaps, is provided by Niall Ferguson, who is usually considered a right-wing historian:

In different ways, belief in determinist theories made all the great conflicts . . more rather than less likely. Ultimately, as this book [Virtual History] seeks to argue, those who died in these conflicts were the victims of generally chaotic and unpredictable events which could have turned out differently ... In this light, perhaps the best answer to the question "Why bother asking counterfactual questions?" is simply: What if we don't? Virtual history is a necessary antidote to determinism. (Ferguson 88-89)

Here, it is clear that virtual history is more than just the kind of gesturing at counterfactual history that characterizes the What If? books. What is lacking from Ferguson's theoretical introduction, but is implied by his afterword, "A Virtual History, 1646-1996", is that in order for virtual history to be such an antidote it has to adopt the narrative techniques of satire and parody. Ferguson employs comic inversion to subvert the teleology inherent to traditional narrative form such that, to pick a few examples, Marx becomes a millennial Jewish prophet who spent his life in 
This is a pre-copyedited version of an article accepted for publication in (Extrapolation -Wooster Oh-) following peer review. The definitive publisher-authenticated version is available through the University of Texas Press.

prison but "indirectly influenced a host of Orthodox imitators in Russia" (421-22); JFK launches a military intervention "in support of Ho Chi Minh's Vietnamese revolt against the Japanese-backed regime of Ngo Dinh Diem" (438); and the West collapses in 1989-90 (440). This satirical virtual history saturates The Separation as we learn in passing of the R. A. Butler government and the Conservative "No" campaign against the EU in the early 1970s led by former Dam Buster, Sir Guy Gibson (20). Or of how Nixon succeeded Stevenson as US President in 1960 and it was all downhill from there ... (208). Perhaps this operates most tellingly in what we learn of the Republic of Masada, which was declared on the island of Madagascar in 1962 after a struggle for independence by the Jews who had been deported there en masse following the 1941 armistice (24). A letter from the novel's present in 1999 connects with our own present:

Don't be put off by recent news of the fighting and terrorism on this large island. We are well aware here how our country sometimes appears from abroad. The government has got the measure of the insurgents and the problem is well in hand. The native Malagasy are largely confined to their area of the island and next year they'll be given a measure of self-government. That should almost certainly satisfy their demands. In the meantime, life in the big cities is modern, convenient and extremely pleasant (215).

However, The Separation is more than just a brilliant satire. Consider the extract (Part II, Chapter 16, 116-131) available on Priest's website and glossed as covering some of the main themes of the book. This is taken from J. L.'s memoirs and thus refers to our world and not the alternate one of Gratton. After recovering from injuries sustained by being shot down, J. L. is chosen to spend some time working as an ADC to 
This is a pre-copyedited version of an article accepted for publication in (Extrapolation -Wooster Oh-) following peer review. The definitive publisher-authenticated version is available through the University of Texas Press.

Churchill. This work consists of touring the bombed streets of London in an open car with Churchill, who clad in familiar black hat and coat, and equipped with cane and cigar, periodically cries out "Are we downhearted?" J. L. comes to an unsettling conclusion:

I quickly realized what the other ADCs must also have known, but which none of us ever admitted or discussed. The cheerful, charismatic man who toured the bombed-out streets and homes of London's East End, who smilingly received the cheers and shouts from the crowds, who gamely puffed his cigars and uttered the familiar words of patriotic encouragement and defiance, was not Winston Churchill at all.

I do not know who he was. Physically he was almost identical to Churchill, but he was not the great man himself. He was a double, an actor, a paid imposter (131).

It is possible to read this doubling as a consequence of myth. Barthes writes: "What is characteristic of myth? To transform a meaning into form" (Barthes 142). One could argue that Priest's new myth "steals" the meaning out of our well-known wartime Churchill, reducing him to only an empty form. Likewise, the novel suggests that our Hess, the "madman" who flew a Messerschmitt to Scotland on 10 May 1941 and was to spend the rest of his life confined at Spandau, is only the emptied form of a powerful (albeit still unpleasant) peacemaker who took over from Hitler after successfully concluding the armistice. When J. L., still working for Churchill, is dispatched to assess the imprisoned Hess, he concludes that he too is a substitute, a double (147-52, 167-78). 
This is a pre-copyedited version of an article accepted for publication in (Extrapolation -Wooster Oh-) following peer review. The definitive publisher-authenticated version is available through the University of Texas Press.

Doubling, and the attendant pain of separation from the double, has been a central theme of Priest's work throughout his long career (for which, see Butler) but one that has dramatically intensified in recent novels such as The Prestige (1995) and The Extremes (1998). Another constant theme in Priest's work, the desire of his characters to escape from the fictions in which they are contained, has become increasingly combined with the desire to become whole again (see Hubble 2005a). Where The Separation breaks new ground is in its linking of the pain of doubling and separation with history. History is always virtual. History is always mythic. History always empties the meaning out of people and leaves them as empty shells. This comparison becomes explicit in Joe's reflections on his brother:

For many years we had been so close: inseparable, our parents used to say about us ... We both tended to drift in a state of abeyance if we were separated... for the last five years ... we had been almost completely separated, first by choice then more recently by the conditions of war.

Had we been drifting into abeyance once more, without each other? (366)

The Encyclopedia of Science Fiction suggests that the protagonist of Priest's 1974 novel Inverted World expresses a "haunted lassitude" that is characteristically British. What is this Britishness but a seemingly interminable drifting in a state of abeyance resulting from the separation of form and meaning that is myth or, as we more commonly label it, history (for examples, see Hubble 2005b). In The Separation, the desire to become whole is expressed as the desire to escape from history itself. J. L. repeatedly "awakes" from his accident — which is fatal to him in Joe's universe - to successively modified futures $(46,58,76)$ including a brief spell in which he recovers his brother's memories (50-51) before he finds himself in our world. However, the 
This is a pre-copyedited version of an article accepted for publication in (Extrapolation -Wooster Oh-) following peer review. The definitive publisher-authenticated version is available through the University of Texas Press.

fact that at one point he resorts to pretending to be Joe (155) for the sake of Joe's German Jewish wife, Birgit, with whom he is having an affair, suggests that he is the empty form and that it is brother who carries the meaning of the novel. From this perspective, Joe's repeated reawakenings from his own accident $(303,308)$ and after other events such as the bombing of Coventry $(315,318)$, can be seen as an attempt to wake up to the peace which eventually comes to pass. Here, the counterfactuals allow a process of trial and error - a core function of virtual history, which Ferguson sees as analogous to Richard Dawkins's concept of genes as "survival machines":

[Dawkins's] theory of evolution is "blind to the future"-Nature has no predestination blueprint. Indeed, the whole point about evolution is that replicator molecules (such as DNA) make and reproduce mistakes, so that "apparently trivial influences can have a major impact on evolution". "Genes have no foresight, they do not plan ahead." ... Thus those organisms which survive the slings and arrows of fortune are those best designed to do so: . . ."Those individuals whose genes build brains in such a way that they tend to gamble correctly are as a direct result more likely to survive, and therefore to propagate those same genes. Hence the premium on the basic stimuli of pain and pleasure, and the abilities to remember mistakes, to simulate options and to communicate with other 'survival machines'." (Ferguson 75)

This is where Priest's version of virtual history departs from Ferguson's, because while pleasure and pain remain inescapably part of what it is to be human, it is not necessary to remain blind to the future. Ultimately, the novel rejects even the alternate history of the 1941 armistice as Joe finds himself once again returned to the ambulance following his accident (462) and the book closes with him "dreaming of waking to a better future" (464). The Separation, therefore, perfectly illustrates the 
This is a pre-copyedited version of an article accepted for publication in (Extrapolation -Wooster Oh-) following peer review. The definitive publisher-authenticated version is available through the University of Texas Press.

logic of the other great alternate history written so far in the twenty-first century, Kim Stanley Robinson's The Years of Rice and Salt:

"... These historians who talk about employing counterfactuals to bolster their theories, they're ridiculous. Because no one knows why things happen, you see? Anything could follow from anything. Even real history tells us nothing at all. Because we don't know if history is sensitive, and for want of a nail a civilization was a lost, or if our mightiest acts are as petals on a flood, or something in between, or both at once. We just don't know, and the what ifs don't help us work it out."

"Why do people like them so much then?"

Kirana shrugged, took a drag on her cigarette. "More stories ... Perhaps it would be better just to focus on the future."

"You, a historian, say this? But the future can't be known at all!"

"Well, but it exists for us now as a project to be enacted." (Robinson 673)

\section{Works Cited}

Anderson, Perry. "Force and Consent." New Left Review [Second Series] 17 (September-October 2002): .

Barthes, Roland. Mythologies. Translated by Annette Lavers. London: Paladin, 1973.

Bobbitt, Philip. The Shield of Achilles: War, Peace, and the Course of History. London: Penguin, 2003.

Butler, Andrew M., ed. Christopher Priest: The Interaction. London: Science Fiction Foundation, 2005. 
This is a pre-copyedited version of an article accepted for publication in (Extrapolation -Wooster Oh-) following peer review. The definitive publisher-authenticated version is available through the University of Texas Press.

Clute, John, and Peter Nicholls, eds. The Encyclopedia of Science Fiction. London: Orbit, 1993.

Cowley, Robert, ed. What If? London: Pan, 2001.

—. More What If? London: Pan, 2003.

Davis Hanson, Victor. "Persian Victory at Salamis." What If? Ed. Robert Cowley. London: Pan, 2001.

Evans, Richard J. In Defence of History. London: Granta Books, 1997.

Ferguson, Niall, ed. Virtual Histories: Alternatives and Counterfactuals. London: Picador, 1997.

Holland, Cecelia. "Normans Repulsed at Hastings." More What If? Ed. Robert Cowley. London: Pan, 2003.

Hubble, Nick. "Priest's Repetitive Strain.” Ed. Andrew M. Butler. Christopher Priest: The Interaction. London: Science Fiction Foundation, 2005a.

-------. "Five English Disaster Novels, 1951-1972." Foundation 95 Autumn 2005 b.

Lukacs, John. Five Days in London, May 1940. New Haven: Yale University Press, 2001.

Orwell, George. Review of Mein Kampf, New English Weekly 21 March 1940. Complete Works. Ed. Peter Davison. Vol. XII. London: Secker and Warburg, 2000.

Priest, Christopher. The Separation. London: Simon and Schuster, 2002.

Robinson, Kim Stanley. The Years of Rice and Salt. London: HarperCollins, 2003.

http://members.aol.com/chrpr997/index.htm

http://members.aol.com/chrpr997/sepread.htm 